\title{
Interactive E-Module Development in Multimedia Learning
}

\author{
Nurhikmah H', Abdul Hakim², M. Syakir Wahid3 \\ DOI: $10.35445 /$ alishlah.v13i3.863
}

\begin{tabular}{l}
\hline Article Info \\
\hline Keywords: \\
$\begin{array}{l}\text { Development; } \\
\text { interactive e-modul; } \\
\text { multimedia }\end{array}$
\end{tabular}

Kata kunci: Pengembangan; e-modul interaktif; multimedia pembelajaran

\begin{abstract}
This study aims to develop interactive e-modules in the Multimedia Learning Course and to know the validity, practicality of the effectiveness of developing interactive e-modules in Multimedia Learning subject. This research method used Research and Development (R \& D), which focused on developing smartphonebased learning media, especially Android. The development model used the Alessi and Trollip development model, consisting of 3 stages: planning, design, and development. This research was conducted at Makassar State University with 45 students and one lecturer in multimedia learning. Interactive e-modules are used in multimedia learning courses to assist and facilitate lecturers in the learning process. Interactive e-modules were developed and validated by material experts and media experts, with the results of material validation obtained an average score of 4.9 (very valid) and media experts obtained an average score of 4.1 (valid) so that interactive e-modules can be tested in the field to determine the practicality and effectiveness with the results shown in the category of very practical and very effective. Based on the results found, it can be concluded that interactive emodules are practical and effective in the learning process in multimedia learning courses at the Education Technology Study Program, Makassar State University.
\end{abstract}

\begin{abstract}
Abstrak
Penelitian ini bertujuan untuk pengembangan e-modul interaktif pada Mata Kuliah Multimedia Pembelajaran, dan mengetahui validitas, kepraktisan keefektifan pengembangan e-modul interaktif pada Mata Kuliah Multimedia Pembelajaran. Metode penelitian ini menggunakan Penelitian Pengembangan yang difokuskan untuk mengembangkan media pembelajaran berbasis smartphone khususnya android. Model pengembangan yang digunakan mengacu pada model pengembangan Allessi and Trollip, yang terdiri atas 3 tahap yaitu: perencanaan (planning), desain (design), dan pengembangan (development). Penelitian ini dilakukan di Universitas Negeri Makassar dengan subjek penelitian 45 mahasiswa dan 1 dosen mata kuliah multimedia pembelajaran. E-modul interaktif digunakan dalam mata kuliah multimedia pembelajaran untuk membantu dan memudahkan dosen dalam proses pembelajaran. E-modul interaktif dikembangkan dan divalidasi oleh ahli materi dan ahli media, dengan hasil validasi materi diperoleh skor rata-rata 4,9 (sangat valid) dan ahli media diperoleh skor rata-rata 4,1 (valid) sehingga e-modul interaktif dapat diuji cobakan di lapangan untuk mengetahui kepraktisan dan keefektifan dengan hasil menunjukkan pada kategori sangat praktis dan sangat efektif. Berdasarkan dari hasil yang ditemukan dapat disimpulkan bahwa e-modul interaktif praktis dan
\end{abstract}

\footnotetext{
${ }^{1}$ Prodi Teknologi Pendidikan Universitas Negeri Makassar, Makassar, Indonesia Email: nurhikmah.h@unm.ac.id

2 Prodi Teknologi Pendidikan Universitas Negeri Makassar, Makassar, Indonesia

Email: abdul.hakim7308@unm.ac.id

3 Prodi Teknologi Pendidikan Universitas Negeri Makassar, Makassar, Indonesia

Email: syakirwahidart@gmail.com
} 
efektif digunakan dalam proses pembelajaran pada mata kuliah multimedia pembelajaran pada Prodi Teknologi Pendidikan Universitas Negeri Makassar.

\section{INTRODUCTION}

Education is currently expanding rapidly, necessitating a variety of types of innovations to improve the overall quality of education. These innovations include improvements in the quality of teachers and educators, curriculum development, learning innovation, and the completeness of facilities and infrastructure, among other things. Lecturers must be more innovative and creative in motivating students to learn optimally in both the classroom and independent study to improve the learning process. This is especially important during a pandemic when students are required to stay at home. Point 2 of Circular Letter Number 4 of 2020, which discusses the Implementation of Education Policies in the Emergency Period for the Spread of Coronavirus Disease (Covid-19), stated that: (a) learning from home through online/distance learning is carried out to provide a meaningful learning experience for the curriculum for class and graduation, (b) learning from home is focused on life skills education, including regarding the Covid 19 pandemic, (c) learning from home is carried out to provide a meaningful learning experience for the curriculum Education can also benefit from electronic media in the learning process that is carried out remotely, one of which is the use of video conferencing software.

The development of teaching materials is very varied because there are many forms of teaching materials in the form of printed, audio, audio-visual and interactive. One of the teaching materials that has changed is teaching materials in the form of modules because the modules were initially only in the form of print but now can be in the form of electronic modules (e-modules) or non-printed modules that can be integrated into many media such as visual, audio, audio-visual and multimedia (Darmawan, 2016), thus making the module interactive. Concerning the above statement, Dwiyoga (2013) in Suwatra et al. (2018) states interactive modules can make it easier to include elements of sound, video, animation and simulation. The development of the module occurs but it does not change the characteristics of the module where the lecturer uses it as a tool to assist in the learning process so that learning can be directed and achieve the learning objectives that have been set. In connection with this opinion, according to Zulkarnain (2015) in Linda et al. (2018), the module is a learning tool that contains materials, methods, limitations, and steps that are used systematically and attractively to achieve the expected competencies according to the level of complexity. From the opinion above, it can be seen that using the module is very important in the learning process.

According to Chaeruman (2014) states that the development of interactive e-modules has several characteristics regarding the nature of e-modules, namely (1) self-paced; allows it to be learned on its own, anytime, anywhere according to its conditions and pace of learning (2) self-instruction; selflearning contains learning activities, (3) self-contained; contains all learning activities, (4) modular/chunking; broken down piece by piece and discussed in depth. Interactive e-module means that there is two-way communication or more. This is in line with Munir's opinion (2013) that interactive has to do with two-way communication or more communication components. Added the opinion of Adisusilo (2014) opinion in interactive itself has a principle that implies that teaching is not just conveying knowledge from educators to students. Still, teaching is considered a process of regulating an environment that can stimulate students to learn" (p. 87).

The development of interactive e-modules has several characteristics according to Chaeruman (2014) regarding the nature of e-modules, namely (1) self-paced; allows it to be learned on its own, anytime, anywhere according to its conditions and pace of learning, (2) self-instruction; self-learning, contains learning activities, (3) self-contained; contains all learning activities, (4) modular/chunking; broken down piece by piece and discussed in depth. This study focused on developing interactive emodules for multimedia learning courses after discovering that online learning was ineffective and that printed books and other teaching materials were inadequate, among other things (Sujanem et al, 2020, Yunita, A., Suyidno, S., \& Syahmani, S. 2021). Educational technology at Makassar State University 
focuses on providing students with an understanding and application of concepts, approaches, learning and learning methods, as well as relationships with other components, learning problems and difficulties. This course emphasizes multimedia learning in the program's Educational Technology Study Program. score. Students in multimedia learning courses are also encouraged to learn more about multimedia devices classified into two categories: software and hardware. Munir (2013) defines multimedia as a collection of computer-based media and communication systems that have a role in building, storing, sending, and receiving information in the form of text, graphics, audio, video, and so on in accordance with Gayeski (1993). Multimedia is a presentation tool that makes use of a variety of media. Hardware includes cameras, desktops, laptops, and various other devices.

Additionally, interactive e-modules can be used in both online and offline classrooms (Adawiyah, R., and Susilawati, L. A. 2020; Danirmala, 2020; Dankbaar, 2017; Erna, M., and Anwar, L. 2021; Fadieny, N., and Fauzi, A, 2021; Hendriyani, Y., Ambiyar, S., and Effend A number of studies, such as Cloonan et al., (2020), back up this claim, showing that students, both experienced and new to the subject, gain knowledge and confidence as a result. McNamara et al. (2020) conducted research that found that online interactive e-modules played an important role in improving students' critical thinking skills and providing them with greater independence in the process of skill improvement. A 10 to 15-minute online course with no more than one or two learning concepts and a mix of teaching and assessment tools, such as video clips, direct instruction, gaming elements, and social media platforms, is what we call an e-learning "module."

Student behaviour may change as a result of students using multimedia as a learning tool in multimedia courses besides just providing knowledge of software and hardware. According to Sani, one way to tell if a student is learning is to look at how their behaviour changes as a result of what they've learned (2019). When a person's behaviour changes due to strict conditions and reinforcement, the individual is said to be learning. According to the theory of Mayer and Fiorella (2014) cited in Campen et al. (2020), learning is most effective when two senses are used, namely visual and auditory, in working memory. As a result, multimedia learning is essential because it can help students meet their learning objectives.

Students were asked to fill out a Google form (online) to identify their learning preferences and interest in using interactive e-modules, and this information was gathered. The characteristics of multimedia learning courses, such as the use of multimedia and software and hardware, were considered in the development of interactive e-modules. The researcher is confident that an interactive e-module will be developed based on the findings above and the course's characteristics, making it easier for students to study in class or study on their own.

\section{METHOD}

This research used the type of Research and Development, commonly referred to as R \& D. Research and Development, to produce a product. The development model used is the Allesi and Trollip Model (Alessi et al., 2001), which consists of 3 stages: planning, design and development, followed by attributes that are always present in each stage, namely, standards, ongoing evaluation, project management. Researchers determined the subject aim to provide limits on what will be studied. The trial subjects were one learning media expert, one content or learning material expert, one multimedia learning subject lecturer, five small group trials and twenty-nine large group trials. A random sampling technique determined the trial subjects.

The method of data collection was an important part of the research. Once a research proposal has been approved, this stage is where the actual research takes place. Questionnaires and interviews are the data collection methods employed in this development research. We looked at the data to get a better idea of what was produced. Qualitative techniques and descriptive statistical analysis were used to describe and develop data collected from the development results, validation results, and student and lecturer responses in a trial design to produce an interactive e-module. This learning material and media experts conducted a qualitative descriptive analysis to process their findings. This type of 
qualitative data analysis was used to compile input, feedback, criticism, and improvement suggestions using the results of questionnaires and interviews. In descriptive statistical analysis, this method was used to process data obtained through questionnaires in percentages that describe the situation. Validation, practicality, and effectiveness tests yielded their results.

\section{FINDINGS AND DISCUSSION}

This development research was carried out starting from April 1, 2020, to July 9, 2021, at the Education Technology Study Program State University of Makassar, so the research results were obtained through an overview of the need for developing interactive e-modules as teaching materials used in the learning process. Research on the development of interactive e-modules using the Alessi and Trollip development model with several stages, including the planning, design and development stages. The development of interactive e-modules has gone through several tests to obtain valid, practical and effective teaching materials so that they can be applied in the learning process of multimedia learning courses at the Education Technology Study Program State University of Makassar.

\section{Planning Stage}

An interactive e-planning module's stage began with the researcher determining the purpose of making teaching materials, identifying student characteristics, creating planning documents, determining resources sources, and conducting interviews with course lecturers. The process of identifying needs can be referred to as a means or a way to maintain the desired relationship individually or in groups, as well as a means to support his own understanding of the relationship, based on the aspects previously mentioned (Azwar, 2005). The curriculum can be found in the section defining the field and scope of researchers (oo1-Dokumen kkni.Pdf, nd). In order to meet KKNI curriculum requirements, a lecturer's RPS must include a number of things outlined in article 12 paragraph 2, including a) the name and course code, semester, credits, and name of lecturer; b) The learning outcomes of graduates charged to the courses; c) The final capabilities planned at each learning stage in order to meet graduate's learning outcomes; d) (Permendikbud No. 49 of 2014 concerning National Standards for Higher Education as Curriculum Reference, nd). In the interactive e-module based on RPS, lecturers of research subjects can determine what material should be included in the interactive e-module, which includes: a) the concept of multimedia learning; b) theories of multimedia learning; c) the principles of multimedia learning; and d) presentation software.

\section{Identify the students' characteristics}

The next part was to identify student characteristics. This identification process was carried out by distributing an online questionnaire (google form) which takes approximately one week due to lack of initiative, so students need to be reminded repeatedly to fill out a needs identification questionnaire. The questionnaire used pays attention to several things in the form of the learning process, the form of teaching materials used, student interest in media in learning, and facilities and infrastructure that can be used in learning. The questionnaire results show a positive response or require innovative teaching material in the online learning process and support facilities and infrastructure that can be used in learning.

\section{Documentation Planning}

The next part to do to make a planning document, in this aspect it consisted of materials and assessment instruments. The determination of the material is based on the RPS of the course lecturers, while the assessment instruments are in the form of a material expert questionnaire, media experts, student responses and lecturer responses. In the assessment instrument, the material expert paid attention to assessing the content, language and quality of learning. Media experts paid attention to physical assessments, the suitability of choosing the type of font, appearance, language and media. For student responses, see the suitability of learning objectives with materials and media, appearance, ease of use of e-modules and suitability of media that support the content of e-modules. And for the lecturer's response to pay attention to the suitability of learning objectives with materials and media, ease of use of e-modules, display of e-modules, 


\section{Determine Sources}

The next section was to determine the sources for developing interactive e-modules in the form of platforms and supporting facilities and infrastructure to run the developed products. After seeing the results of identifying needs, researchers can determine things that support access to interactive emodules so that it is determined that the development of this interactive e-module can later be used on a mobile or on a PC/laptop using HTML format.

a. Interview

The last part of the planning stage was conducting interviews, researchers conducted interviews with a free interview model to one of the lecturers of multimedia learning courses regarding product development, materials and media that will be included in interactive e-modules. The results of the interviews with lecturers of multimedia learning courses showed a positive response that was in line with the needs of students, while what was discussed in the free interview was about products with the development of teaching materials that can be used by mobile. Meanwhile, regarding materials and media, it is highly recommended to follow the RPS so that learning remains focused and achieves goals. So it was concluded that in this development, an interactive e-module was developed in the multimedia learning course of the Education Technology Study Program State University of Makassar.

\section{Design Stage}

The design takes the planning process results, then prepares supporting materials, make flowcharts, and prepare materials. Preparation of supporting materials in the form of books by the RPS of the course lecturers. After going through several considerations as described earlier, the books used are Munir's book entitled multimedia concepts and applications in education and Arsyad's book with the title of learning media. The section on making the flowchart is an initial description/initial framework of the development of this interactive e-module which is the basis for making the flow of the e-module storyboard by considering the learner's learning flow. Prepare the material referred to here in the form of supporting material in images, videos and animations related to the material to be presented. The materials prepared were taken from various clear sources such as youtube about the introduction of software as well as pictures taken from articles, and of course by the learning objectives to be achieved. The final result of this design stage is getting an interactive e-module model framework and determining the supporting materials to be used. At this stage, it takes approximately half a month to determine the outline form of the interactive e-module and determine the supporting materials.

\section{Development Stage}

This is the final step in the Alessi and Trollip software development model before it is released into production. Here, interactive e-modules are first developed, then evaluated and then revised. Interactive e-module production, alpha testing, revision, beta testing, and final revision are part of this stage. Kvisoft Flipbook Maker and Canva and Visme were among the platforms and software used in the early stages of creating interactive e-modules. It was decided to use Canva to develop interactive emodules based on the user's creativity and the ability to use e-modules in various formats such as PDF and links, as well as print them after considering its accessibility (PC, Smartphone, and tablet). An interactive e-module was developed using the Canva platform, and its advantages and disadvantages were discovered. It is possible to create interactive e-modules using Canva because the platform's tools are simple, the number of templates available is large, and there is room for creativity in the design process. Other advantages include the ability to incorporate media from external sources, such as images, videos, and graphics, as well as the ability to create additional buttons through the use of hyperlinks. If you want to get the most out of Canva's features, you'll have to pay, and if you open the following page, it will open a new page/tab in your web browser every time you do so.

The alpha test was carried out by two experts/validators, one from the field of materials and the other from the media. Individuals who have tested interactive electronic modules are asked to provide feedback on their experiences. Interactive e-module evaluation questionnaires were completed by media and material validity assessors. They've been rated 98 per cent by the material validator and 82 
per cent by the media validator based on the results of their respective assessments. Students who validate their work receive feedback that they can use to improve the interactive e-module.

Thus, alpha testing is an alpha test followed by a beta testing process in order to improve the results. Final testing will be done on students and lecturers as potential customers for this product. To help students learn multimedia materials on their own or in groups, they can use interactive e-modules. The beta test results were analyzed by comparing data from small and large groups. When conducting small group trials for groups of 4-15 participants and large groups of 15-50 participants, Arikunto (2013 p. 254) stated that three groups of 7 students each for groups of 45 participants were used. In contrast, the lecturer's e-module response rate was 97.5 percent with a practical category. Asynchronous beta testing is carried out using the LMS and Zoom platforms. Researchers decided to use an LMS called Sham Ok and the Zoom platform to help students learn more effectively because multimedia learning places more emphasis on theory and practice (Hikmat et al., 2020). Researchers found it difficult to gather students to take a series of tests during the beta test because of students' limited distance and time adjustment.

Interactive e-modules are electronic teaching aids that help students and lecturers learn more diverse, efficient, and effective. Learners can benefit from the convenience of e-learning modules, which can be used individually and in groups. As a result of these trials, it has been proven possible to use interactive e-module products to help lecturers, especially for students who can study and from any location. Based on Cucus and Aprilinda (2016) findings, the use of multimedia content in e-learning can lead to better learning outcomes for students. Using interactive e-modules in both online and offline classrooms can help students improve their learning comprehension, which can increase the understanding of the material of those students who use it (Dankboar, Kowitlawakul, Murai, and Padullo, 2017; Padullo, 2021). Cloonan et al. (2020) found an increase in knowledge and confidence for both experienced and novice students, and these findings supported this study. McNamara et al., (2020) conducted research that found that online interactive e-modules played an important role in improving students' critical thinking skills and providing them with greater independence in the process of skill improvement. A 10 to 15 -minute online course with no more than one or two learning concepts and a mix of teaching and assessment tools, such as video clips, direct instruction, gaming elements, and social media platforms, is what we call an e-learning "module."

As a result, interactive e-modules are expected to improve student learning outcomes and solve problems that exist in the learning environment of the Covid-19 pandemic. Some examples of the product used in this study are as follows:
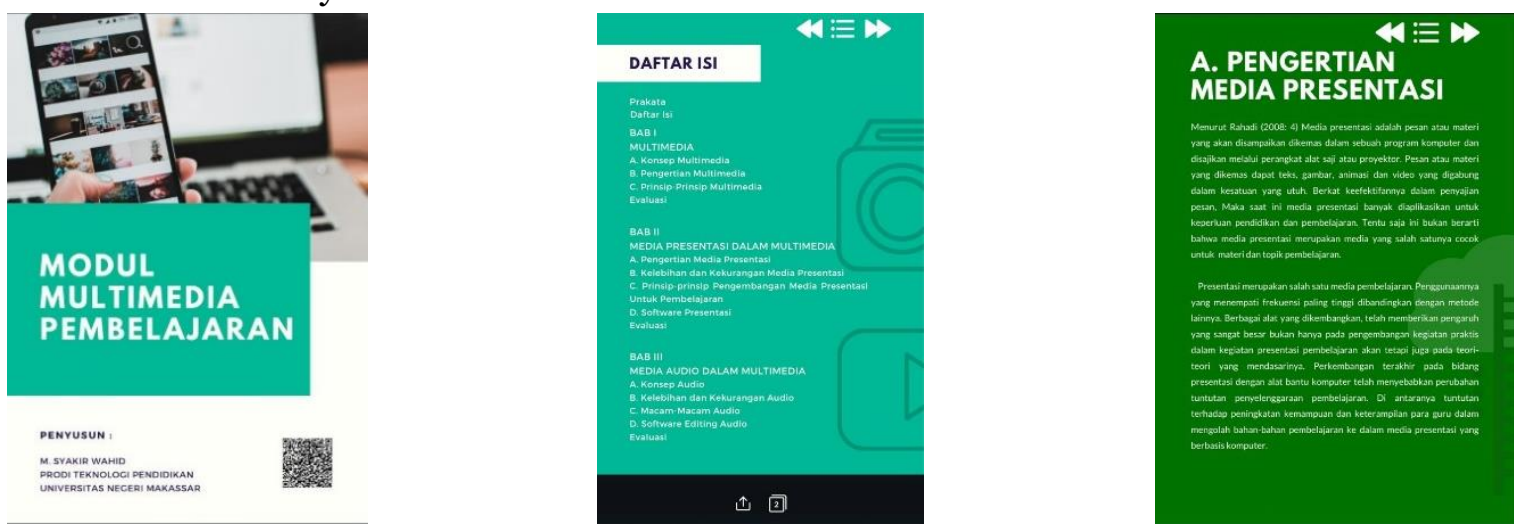

Figure 1. Product display

\section{CONCLUSION}

The study's findings indicated that the planning stage resulted in the establishment of multimedia learning courses and the identification of students' characteristics in terms of learning styles such as visual and auditory, as well as the establishment of the platform using Canva. The design stage results 
in a storyboard that includes a home page, table of contents, materials, and evaluation. Meanwhile, it develops validated, practical, and effective products for online learning. The limitations of this research manifest themselves in the form of seriousness in student learning when the research becomes uncontrollable by the researchers. Suggestions for additional research are expected to include the development of more targeted interactive e-modules or the creation of content that is video, image, or animation-specific.

\section{REFERENCES}

Adawiyah, R., \& Susilawati, L. A. (2020). Implementation of an Interactive E-Module to Improve Concept Understanding of Students.

Adisusilo, S. 2014. Pembelajaran nilai karakter: Konstruktivisme dan VCT sebagai inovasi pendekatan pembelajaran afektif. Jakarta: PT Raja Grafindo Persada.

Akbar, S. D. 2013. Instrumen perangkat pembelajaran. Bandung: PT Remaja Rosdakarya.

Alessi, S. M., Trollip, S. R., \& Alessi, S. M. 2001. Multimedia for learning: Methods and development (3rd ed). Allyn and Bacon.

Arikunto, Suharsimi. 2013. Prosedur Penelitian suatu Pendekatan Praktik. Jakarta: Rineka Cipta

Azwar, Saifuddin. 2005. Sikap Manusia: Teori dan Pengukurannya. Yogyakarta: Pustaka Pelajar.

Chaeruman, Uwes Anis. 2014. Petunjuk Teknis Bimbingan Praktek Kerja Individu/Kelompok Pelatihan Penulisan Modul Online. Jakarta: Pusat Teknologi Informasi dan Komunikasi the representational fluency and conceptual Pendidikan Kementrian Pendidikan dan Kebudayaan.

Cloonan, M. R., Cloonan, D. J., Lynn Schlitzkus, L., \& Fingeret, A. L. 2020. Learners with Experience in Surgical Scrub Benefit from Additional Education with an Interactive E-Learning Module. Journal of the American College of Surgeons, 231(4), e196. https://doi.org/10.1016/j.jamcollsurg.2020.08.521

Cucus, A., \& Aprilinda, Y. 2016. Pengembangan E-Learning Berbasis Multimedia untuk Efektivitas Pembelajaran Jarak Jauh. Explore: Jurnal Sistem informasi dan telematika (Telekomunikasi, Multimedia dan Informatika), 7(2). http://dx.doi.org/10.36448/jsit.v7i2.765

Darmawan, D. 2016. Mobile Learning Sebuah Aplikasi Teknologi Pembelajaran. Jakarta: PT Raja Grafindo Persada.

Dankbaar, M. E., Richters, O., Kalkman, C. J., Prins, G., Ten Cate, O. T., van Merrienboer, J. J., \& Schuit, S. C. (2017). Comparative effectiveness of a serious game and an e-module to support patient safety knowledge and awareness. BMC medical education, 17(1), 1-10. https://doi.org/10.1186/s12909-016-0836-5

Danirmala, M., Asrowi, A., \& Musadad, A. A. (2020). Integration of Environmental Issues in Electronic Module of Social Studies Learning in Junior High School. https://eudl.eu/doi/10.4108/eai.211-2019.2294862

Eko Putro Widoyoko. 2009. Evaluasi Program Pembelajaran. Yogyakarta ; Pustaka Belajar.

Erna, M., \& Anwar, L. (2021). Interactive E-Module Using Zoom Cloud Meeting Platform to Reduce Misconceptions on Salt Hydrolysis Material. Journal of Education and Learning (EduLearn), 15(2), 283-290. http://dx.doi.org/10.11591/edulearn.v15i2.18460

Fadieny, N., \& Fauzi, A. (2021). Usefulness of E-module Based on Experiential Learning in Physics Learning. International Journal of Progressive Sciences and Technologies, 25(1), 410-414. http://dx.doi.org/10.52155/ijpsat.v25.1.2783

Hendriyani, Y., Ambiyar, S., \& Effendi, H. (2020, December). The Development of Interactive Project Based E-Module in Visual Program Course. In 2nd International Conference Innovation in Education (ICoIE 2020) (pp. 236-240). Atlantis Press. https://dx.doi.org/10.2991/assehr.k.201209.226

Hikmat, H., Hermawan, E., Aldim, A., \& Irwandi, I. 2020. Efektivitas pembelajaran daring selama masa pandemi Covid-19: Sebuah survey online. LP2M. http://digilib.uinsgd.ac.id/id/eprint/30625

Knoop-van Campen, C. A., Segers, E., \& Verhoeven, L. 2020. Effects of audio support on multimedia learning processes and outcomes in students with dyslexia. Computers \& Education, 150, 103858. https://doi.org/10.1016/j.compedu.2020.103858

Kowitlawakul, Y., Chan, M. F., Tan, S. S. L., Soong, A. S. K., \& Chan, S. W. C. (2017). Development of an e-Learning research module using multimedia instruction approach. CIN: Computers, Informatics, Nursing, 35(3), 158-168. https://doi.org/10.1097/cin.0000000000000306 
Kumala, F. N., Ghufron, A., Astuti, P. P., Crismonika, M., Hudha, M. N., \& Nita, C. I. R. (2021, April). MDLC model for developing multimedia e-learning on energy concept for primary school students. In Journal of Physics: Conference Series (Vol. 1869, No. 1, p. 012068). IOP Publishing. https://10.1088/1742-6596/1869/1/012068

Kurniati, R. D., Andra, D., \& Distrik, I. W. (2021, February). E-module development based on PBL integrated STEM assisted by social media to improve critical thinking skill: A preliminary study. In Journal of Physics: Conference Series (Vol. 1796, No. 1, p. 012077). IOP Publishing. http://dx.doi.org/10.1088/1742-6596/1796/1/012077

Linda, R. (2018). Interactive E-Module Development through Chemistry Magazine on Kvisoft Flipbook Maker Application for Chemistry Learning in Second Semester at Second Grade Senior High School. Journal of Science Learning, 1(2), 21-25. https://doi.org/10.17509/jsl.v2i1.12933

McNamara, J., Sweetman, S., Connors, P., Lofgren, I., \& Greene, G. 2020. Using interactive nutrition modules to increase critical thinking skills in college courses. Journal of nutrition education and behavior, 52(4), 343-350. https://doi.org/10.1016/j.jneb.2019.06.007

Murai, A. S., Vijayragavan, K., \& Singh, P. (2017). Developing an e-learning module. International Journal

$$
\text { of Farm Sciences, 7(3), }
$$

118-121. https://krishi.icar.gov.in/jspui/bitstream/123456789/26340/1/26.\%201019\%20Murai\%20et \%20al.pdf

Munir, P. D. 2012. Multimedia konsep \& aplikasi dalam pendidikan. Bandung: Alfabeta.

Padullo, Z. M., Fuertes, A. C., Casa-alan, R. M. M., Garalda, J. T., Quintana, E. P., \& Fuertes Jr, D. G. (2021). Using E-Modules in Teaching Technology \& Livelihood Education For The Revitalized Alternative Delivery Mode Program of Holy Spirit National High School. Academic Journal of Digital Economics and Stability, 3, 34-43. https://economics.academicjournal.io/index.php/economics/article/view/30/31

Press.oo1-dokumen_kkni.pdf. (n.d.).

Permendikbud No. 49 Tahun 2014 tentang Standar Nasional Pendidikan Tinggi sebagai Acuan

Kurikulum. (n.d.). 27.

Salinan PERMENDIKBUD 3 TAHUN 2020 FIX GAB.pdf. (n.d.).

Sani, Ridwan Abdullah. 2019. Strategi Belajar Mengajar. Depok: PT. Rajawali Pers.

SE Kemdikbud Menteri Nomor 4 Tahun 2020 Cap.Pdf, (n.d.).

Sujanem, R., Suwindra, I. N. P., \& Suswandi, I. (2020, July). The Effectiveness Of Problem-Based Interactive Physics E-Module On High School Students' Critical Thinking. In Journal of Physics: Conference Series (Vol. 1503, No. 1, p. 012025). IOP Publishing.

Sujarwo, S., Sukmawati, S., Akhiruddin, A., Ridwan, R., \& Siradjuddin, S. S. S. (2020). An analysis of university students' perspective on online learning in the midst of covid-19 pandemic. Jurnal Pendidikan Dan Pengajaran, 53(2), 125-137. http://dx.doi.org/10.23887/jpp.v53i2.24964

Suppan, L., Abbas, M., Stuby, L., Cottet, P., Larribau, R., Golay, E., ... \& Suppan, M. Effect of an ELearning Module on Personal Protective Equipment Proficiency by Prehospital Personnel: WebBased, Randomized Controlled Trial. https://doi.org/10.2196/21265

Suwatra, W., Suyatna, A., \& Rosidin, U. 2018. Development of Interactive E-Module for Global Warming to Grow of Critical Thinking Skills. International Journal of Advanced Engineering, Management and Science, 4(7). https://dx.doi.org/10.22161/ijaems.4.7.7

Travieso, M. (2019). How to Calculate Perimeters: A Multimedia Learning Module for 3rd Grade Parents. http://hdl.handle.net/10211.3/208021

Yunita, A., Suyidno, S., \& Syahmani, S. (2021). The validity of science e-module based on the authentic problem. In Journal of Physics: Conference Series (Vol. 1760, No. 1, p. 012037). IOP Publishing. 